Wilson, S. J., and E. M. Bayne. 2018. Use of an acoustic location system to understand how presence of conspecifics and canopy cover influence Ovenbird (Seiurus aurocapilla) space use near reclaimed wellsites in the boreal forest of Alberta. Avian Conservation and Ecology 13(2):4. https://doi. org/10.5751/ACE-01248-130204

Copyright (C) 2018 by the author(s). Published here under license by the Resilience Alliance.

Research Paper

\title{
Use of an acoustic location system to understand how presence of conspecifics and canopy cover influence Ovenbird (Seiurus aurocapilla) space use near reclaimed wellsites in the boreal forest of Alberta
}

Scott J. Wilson ${ }^{1}$ and Erin M. Bayne ${ }^{2}$

${ }^{1}$ Department of Biological Sciences, University of Alberta, Edmonton, AB Canada, ${ }^{2}$ Department of Biological Sciences, University of Alberta, Edmonton, AB, Canada

ABSTRACT. Standard approaches in acoustic monitoring provide coarse information for understanding songbird behavior, abundance, and habitat use. An alternative approach, acoustic localization, determines accurate bird singing locations from time of arrival differences of songs to microphones in an array. The need to collect spatially accurate data on songbirds is necessary to understand impacts of disturbances characteristic of energy extraction such as wellsites, and how these impacts change following reclamation. Our objective was to use acoustic localization to determine if Ovenbirds (Seiurus aurocapilla) used reclaimed wellsites, and how this behavior changed as a function of canopy cover on wellsites and the presence of conspecifics. We estimated the number of individuals present at each site based on previous data on Ovenbird singing and movement rates. Our hypotheses that use of wellsites by Ovenbirds should increase with increasing canopy cover on the wellsite, and decrease with presence of conspecifics were supported. Technological advances in this method could provide an alternative to conventional methods like territory or spot mapping in the future, when used in combination with other types of data collection.

\section{Utilisation d'un système de localisation acoustique pour évaluer l'influence de la présence de conspécifiques et du couvert forestier sur l'utilisation de l'espace par la Paruline couronnée (Seiurus aurocapilla) près de sites miniers restaurés en forêt boréale albertaine}

RÉSUMÉ. Les approches habituelles de suivis acoustiques fournissent une information sommaire pour la compréhension du comportement, de l'abondance et de l'utilisation de l'habitat d'oiseaux chanteurs. Une approche alternative, la localisation acoustique, détermine la localisation précise des oiseaux chanteurs à partir des différences du temps d'arrivée des chants aux microphones installés en réseau. La collecte de données d'oiseaux chanteurs précises spatialement est nécessaire pour nous permettre de comprendre les effets des perturbations typiques d'activités d'extraction de ressources, telles que l'activité minière, tout comme l'est l'évolution de ces effets suivant la restauration de sites miniers. Notre objectif était d'utiliser la localisation acoustique pour déterminer si les Parulines couronnées (Seiurus aurocapilla) utilisaient les sites miniers restaurés et d'évaluer dans quelle mesure cette utilisation évoluait en fonction du couvert forestier des sites miniers et de la présence de conspécifiques. Nous avons estimé le nombre d'individus présents à chaque site à partir de données antérieures du taux de chant et du taux de déplacement des parulines. Les hypothèses selon lesquelles l'utilisation des sites miniers par les Parulines couronnées devrait augmenter en fonction de l'augmentation du couvert forestier aux sites et diminuer en fonction de la présence de conspécifiques se sont avérées justes. Grâce aux avancées technologiques qu'elle présente, cette méthode peut servir d'alternative aux méthodes conventionnelles comme la cartographie de territoires ou les plans quadrillés, lorsqu'elle est utilisée en combinaison avec d'autres types de collectes de données.

Key Words: acoustic localization; bioacoustics; boreal forest; reclamation; Seiurus aurocapilla

\section{INTRODUCTION}

Bird monitoring increasingly utilizes autonomous recording units (hereafter ARUs) to collect data (Blumstein et al. 2011, Shonfield and Bayne 2017). Standard approaches in bioacoustic monitoring using ARUs provide data that are the functional equivalent of an unlimited radius point count by a human observer. Such data provide coarse information for understanding songbird behavior, abundance, and habitat use (Bayne et al. 2016). The coarse nature of such data stem primarily from challenges in estimation of area sampled and difficulty distinguishing individuals (Ehnes and Foote 2015, Darras et al. 2016, Yip et al. 2017). Certain research questions in songbird ecology, such as local scale response to human disturbances require more precise spatial locations of birds (Bayne et al. 2016). Although spot mapping and territory mapping data can provide such information, field data collection for these methods is time consuming, potentially invasive to birds, and determining information on many individuals or species concurrently is challenging (Bibby et al. 1992, Mennill et al. 2012, Wilson et al. 2014). 
Acoustic localization can be used to collect spatially accurate information on multiple individual songbirds concurrently through use of ARUs (Blumstein et al. 2011, Kirschel et al. 2011). Localization determines singing locations from time of arrival differences of songs to microphones in an array or acoustic location system (hereafter ALS; McGregor et al. 1997, Blumstein et al. 2011). Various taxa including primates (Spillmann et al. 2015), marine mammals (Hayes et al. 2000), amphibians (Jones and Ratnam 2009), and birds (Kirschel et al. 2011, Stepanian et al. 2016) have been surveyed using localization. However, most songbird research using localization has focused on validation of methodology or examination of singing behavior (Mennill et al. 2006, Fitzsimmons et al. 2008, Campbell and Francis 2012). Fewer studies have used localization to understand habitat associations or space use of songbirds in relation to human disturbance.

Ideally, individual birds could be distinguishable by their vocalizations over time to identify individual space use patterns (Kirschel et al. 2011, Petrusková et al.2016). Although individuals within many species show consistency in their songs, vocalizations cannot always be reliably attributed to a specific individual (Mennill 2011). Therefore, to determine the number of individuals, conventional methods such as point counts and spot mapping rely on simultaneous detections of conspecifics through "countersinging events" (Bibby et al. 1992). Localization is well suited for estimation of number of individuals through countersigning events, which we define as songs attributed to different individuals based on their location in space and time. This is based on the logic that singing events greater than a predetermined distance apart, and within a set time interval are unlikely to be the same individual. With knowledge of movement rates and intersong intervals, rules to identify countersinging events using recording technology can be developed. The maximum number of singing locations greater than the predetermined distance apart can then be used to estimate the number of individuals present.

Populations of many songbird species in the boreal forest are declining, and concerns have been raised that oil and gas development may be partially responsible (van Wilgenburg et al. 2013). This development includes hundreds of thousands of onehectare wellsites. Following production, wellsites are required to be actively reclaimed in Alberta (Powter et al. 2012, Bott et al. 2016). Current reclamation criteria use measures of soil, vegetation, and hydrology similarity to a reference condition specific to the site and representative of the predisturbance condition (Powter et al. 2012, Bott et al. 2016). Despite thousands of approved reclamation certificates, there is limited information to describe if wellsites are recovered from a wildlife perspective. Past assessments of songbird responses to wellsites have relied on point counts conducted by humans, and emphasize that the spatial precision at which songbirds are measured has a large effect on the conclusions about wellsite impact (Bayne et al. 2016). Thus, fine scale data on songbird use and avoidance, such as those provided by spot mapping, territory mapping, or acoustic localization are required to assess recovery (Machtans 2006, Lankau et al. 2013). Whether current reclamation criteria results in reduced avoidance or use of wellsites by songbirds remains an unanswered question of interest to policy makers. Knowledge that these sites are recovering effectively for wildlife is important given the costs associated with reclamation. Failure of these wellsites to regenerate over a reasonable time frame will influence the amount of forest habitat available, potentially resulting in detrimental effects on songbird populations in the boreal forest in the long term (Mahon et al. 2016).

Ovenbirds (Seiurus aurocapilla) are found predominantly in mature deciduous forest during the breeding season, but will use regenerating deciduous stands (Bayne et al. 2005a, Haché et al. 2013). At high densities, this species will avoid human disturbances at early stages of regeneration, and use them as territory boundaries. Ovenbirds will use these disturbances increasingly as they regenerate, however, their perception as a territory boundary may persist for a longer period of time (Bayne et al. 2005a, Machtans 2006, Lankau et al. 2013). Ovenbird singing locations indicate territorial behavior, and placement in relation to recovering wellsite footprint should provide evidence of reduced impact of wellsite disturbance. Ovenbirds vocalize frequently, which provides an opportunity to determine many singing locations effectively using acoustic localization (Mennill 2011). Finally, Ovenbird songs are produced from the lower canopy, which limits spatial error in localization due to disparity between microphone and signal height (Wilson et al. 2014).

Our objective was to use acoustic localization to determine how canopy cover and presence of conspecifics influenced how Ovenbirds would use reclaimed wellsites. Our approach estimated the number of individual Ovenbirds present near reclaimed wellsites based on separation of singing events in space and time. Increased detections of Ovenbirds within a wellsite should indicate a bird is more likely to use this area as part of its territory, and thus demonstrates a reduced impact of these sites from an Ovenbird's perspective. We hypothesized that Ovenbirds would avoid wellsites at early stages of regeneration, i.e., limited canopy cover, presumably to limit predation risk and lower quality foraging opportunities, because of absence of leaf litter associated with lack of canopy cover (Lankau et al. 2013). It is expected that Ovenbirds would sing from reclaimed wellsites more frequently as canopy cover increased (Lankau et al. 2013). We also predicted that increasing local abundance of Ovenbirds would influence the probability that an individual would sing from the wellsite because this species appears to use energy sector disturbances, e.g., seismic lines, as territory boundaries (Bayne et al. 2005b, Machtans 2006, Heap et al. 2012, Lankau et al. 2013). Therefore, we hypothesized that use of wellsite edges as territory boundaries would become more evident with increasing local abundance of Ovenbirds, resulting in a decreased proportion of total singing locations on the wellsite (Lankau et al. 2013).

\section{METHODS}

\section{Wellsite selection}

We selected certified reclaimed wellsites $(n=20)$ within $50 \mathrm{~km}$ of the communities of Lac La Biche and Slave Lake, Alberta in the Central Mixedwood Natural Subregion of the Boreal Forest Natural Region (Downing and Pettapiece 2006). We focused on selection of wellsites surrounded by mesic upland ecosites in forests dominated by trembling aspen (Populus tremuloides), and balsam poplar (Populus balsamifera). Understory shrubs in the adjacent forest included alder (Alnus spp.), willow (Salix spp.), and beaked hazelnut (Corylus cornuta). Wellsite footprints were 
an average of $1.03 \pm 0.12$ (mean \pm standard error) hectares in size, determined through digitization of survey diagrams and field measurements (Abacus Datagraphics Limited 2015). An average of $21.6 \pm 3.04$ years had passed since wellsite reclamation certificates were issued. Reclamation certificates were issued an average of $3.71 \pm 0.61$ years after completion of resource extraction. However, vegetation on wellsites may regenerate heterogeneously, in part because of changing development and reclamation practices. For this reason, we selected sites to sample a gradient of woody vegetation recovery ranging from sites with predominantly grass and forb cover, to sites where woody vegetation exceeded five metres in height, i.e., canopy cover, rather than relying on age of wellsites alone to predict vegetation recovery. Each site typically had an adjacent linear feature, i.e., wellsite access road, which was previously used during the resource extraction process. We attempted to select sites surrounded by limited other recent human disturbance, e.g., forest harvest $<30$ years old. The average proportion of area disturbed within a $150 \mathrm{~m}$ radius surrounding the wellsites was $0.18 \pm 0.05$.

\section{Vegetation data collection}

We used the point intercept method to measure canopy cover on reclaimed wellsites (Floyd and Anderson 1987). A 90 m diagonal transect was laid out from a randomly selected corner of the wellsite to the opposite corner. Vegetation height measurements were taken at $3 \mathrm{~m}$ increments for the first and last $30 \mathrm{~m}$, and $1 \mathrm{~m}$ increments for the center $30 \mathrm{~m}$. These data were summarized into percent canopy cover based on presence or absence of vegetation above $5 \mathrm{~m}$ at each sampling location, which ranged from 0 to $100 \%$ at reclaimed wellsites. Canopy cover was used, as it was previously used to explain Ovenbird response to seismic line regeneration, and was correlated with other metrics important to Ovenbirds including percent cover of leaf litter that was determined using the same point intercept transect (Pearson's $r=0.88$; Lankau et al. 2013).

\section{Acoustic data collection}

We used global positioning system (GPS) enabled Wildlife Acoustics SM3 units equipped with external SMM-A1 microphones to construct the ALS (Wildlife Acoustics, Inc., Maynard, Massachusetts, USA). A total of 500 microphones were deployed over the 20 sites ( 25 microphones per site) during the songbird breeding season in 2015 (May 25-June 27) and 2016 (May 26-June 27). Three microphone spacings were used in the study; $35 \mathrm{~m}$ spacing ( $\mathrm{n}=11$ sites), $37.5 \mathrm{~m}$ spacing $(\mathrm{n}=7$ sites $)$, and $50 \mathrm{~m}$ spacing $(\mathrm{n}=2$ sites; Fig. 1$)$. Microphones were deployed at a height of $1.5 \mathrm{~m}$, and spaced an average of $31.4 \pm 0.44 \mathrm{~m}$ apart in a $5 \times 5$ grid (Fig. 1). Arrays covered an average area of 2.13 \pm 0.08 hectares. We determined positions with a horizontal accuracy of $\pm 3.0 \mathrm{~cm}$ using a Hemisphere S320 survey GPS. Positions were determined from the mounted Garmin 16x GPS attached to the recording unit (accuracy $3.28 \pm 0.25 \mathrm{~m}$ ) when not possible to obtain locations using the survey GPS due to dense canopy. This occurred at 200 of the 525 microphone locations. The ALS was deployed, and recordings were collected on 1-5 subsequent days from $05: 30 \mathrm{AM}$ to $08: 30 \mathrm{AM}$ at each site in compressed Wildlife Acoustics' WAC format with a $48000 \mathrm{~Hz}$ sample rate. The GPS clock of the Garmin 16x was used to synchronize recordings within the array to $\pm 1 \mathrm{~ms}$.
Fig. 1. Example countersinging event, where singing events of three Ovenbirds (Seiurus aurocapilla) occurred greater than $37.2 \mathrm{~m}$ apart during the $25.5 \mathrm{~s}$ interval. The labelled vocalizations in the spectrogram that was from the microphone in the center of the wellsite correspond with the labelled spatial locations over the wellsite. Sites varied slightly in microphone spacing and layout.

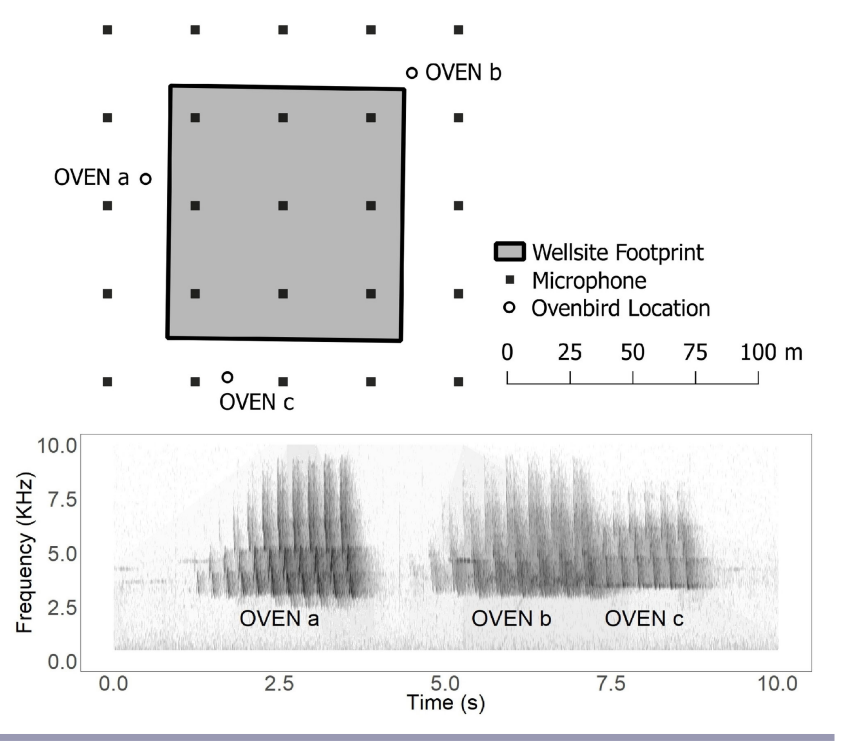

\section{Acoustic data processing}

We processed three hours of morning song, i.e., 05:30-08:30 AM, at each site to target when Ovenbirds are mostly likely to vocalize. Recording files were converted to wav format and spectrograms were visualized using a 512 FFT hamming window in the program Audacity 2.1.3 (Audacity Team 2017). Recordings were visually scanned in groups of four channels to locate Ovenbird songs within the microphone array. Vocalizations were included in further analyses if the entire song was detected clearly on four or more microphones, and was not masked by songs of greater amplitude, or with any fainter singing events for $25 \%$ of the duration of the target vocalization on any channel. Ovenbird identifications were determined manually through acoustic and visual cues from spectrograms. The multichannel track that contained the strongest signal for each singing event was used in subsequent analyses.

Speed of sound was estimated using temperature data from the nearest Environment and Climate Change Canada weather station (Wilson et al. 2014, Environment and Climate Change Canada 2017). The same temperature value was used for all vocalizations occurring within hourly intervals. The weather stations used were an average of $32.3 \pm 2.05 \mathrm{~km}$ from the wellsites. We imported the multichannel tracks, microphone positions, and speed of sound into the MATLAB based program XBAT for analysis (Figueroa and Robbins 2007, MathWorks Inc. 2014). Each vocalization that met the criteria mentioned earlier was annotated. We used the CSE location algorithm (version 2.3) for acoustic localization (Cortopassi 2006). This algorithm determines the time of arrival differences of a signal to different channels in the ALS using pairwise cross correlations of the signal 
between channels (Cortopassi 2006, Campbell and Francis 2012). These time of arrival differences are used to calculate the location of the signal under a known speed of sound and microphone locations (Cortopassi 2006). Each annotated vocalization was localized using a minimum of four channels to estimate positions, and a search radius of $100 \mathrm{~m}$ (Campbell and Francis 2012). This was to achieve the most accurate positions because accuracy of localization degrades with distance from the center of the array (McGregor et al. 1997, Campbell and Francis 2012, Wilson et al. 2014). Singing locations were exported from and visualized in QGIS 2.12.3 (Quantum GIS Development Team 2016). Events were constrained to within $100 \mathrm{~m}$ from wellsite center, to sample an equal area at each site. Vocalizations occurring beyond this buffer were excluded from subsequent analyses.

Playback experiments were performed at one of the study sites to estimate spatial error in localization. Error estimates were determined by calculating the distance between five known locations of a speaker broadcasting Ovenbird playbacks, and the estimated location of the playbacks using XBAT. Experiments were run to determine the average error under the three different spacing of microphones, and the GPS accuracy used to determine microphone locations that were used during the study. In each experiment, the location of the playback speaker was estimated using the survey GPS. At each playback location, a single Ovenbird vocalization was broadcast at $85 \mathrm{~dB}$. In the first experiment, the average error in localization for $35 \mathrm{~m}$ microphone spacing, and microphone positions estimated with the survey grade GPS used at 11 sites, was $2.03 \mathrm{~m}$ ( 5 th percentile: $0.74 \mathrm{~m}$, 95th percentile: 3.44 $\mathrm{m})$. Error increased to an average of $8.75 \mathrm{~m}$ (5th percentile: 4.16 $\mathrm{m}$, 95th percentile: $12.3 \mathrm{~m}$ ) in the second experiment, when microphones were spaced slightly farther apart $(37.5 \mathrm{~m})$ and the microphone positions were estimated from the Garmin 16x GPS attached to the recording unit which occurred at 7 sites. Finally, in the third experiment, with increased intermicrophone distance of $50 \mathrm{~m}$, and when microphone positions were estimated from the Garmin 16x GPS attached to the recording unit that occurred at two sites, the resulting average error was $11.1 \mathrm{~m}$ (5th percentile: $8.19 \mathrm{~m}, 95$ th percentile: $16.2 \mathrm{~m}$ ).

Previous data on Ovenbird territory mapping data, and counts of singing rate were used to estimate Ovenbird movement rates, and average intersong interval for identification of countersinging events. Ovenbird territory mapping data were obtained from Fort Liard, Northwest Territories in 2008 and 2009 (Lankau et al. 2013). Territories were obtained for 58 individuals, based on methods outlined in Lankau et al. 2013. We selected data from a single visit to each bird's territory where the individual was tracked for more than 30 minutes. We determined the 95 th percentile of movement rate by dividing the total distance that the bird moved during the visit, by the length of the visit. The 95th percentile of Ovenbird singing rate was determined from values of singing rate provided by the lhreg package in R (R Core Team 2017, Sólymos et al. 2018). From these data, we determined that the 95 th percentile of singing rate was 2.36 songs per minute or a song every $25.5 \mathrm{~s}$. Within this 25.5 s interval, the $95 \%$ percentile of distance that Ovenbirds would move based on territory mapping data was $37.2 \mathrm{~m}$. Using these values, we determined an estimate of the number of individuals (hereafter hypothesized individuals) at each site by identifying the maximum number of unique Ovenbird songs greater than $37.2 \mathrm{~m}$ apart from all other vocalizations that occurred during the $25.5 \mathrm{~s}$ time intervals (Fig. 1).
Singing events that occurred in the same position were averaged based on estimated error in localization at each site, to represent a single singing location. For example, if average error in localization was estimated to be $2.03 \mathrm{~m}$ at site, and 10 Ovenbird songs within a $2.03 \mathrm{~m}$ radius, the location of these events would be averaged to represent a single singing location. These averaged singing locations were then classified as occurring within the wellsite footprint, or within the adjacent forest. The proportion of singing locations within the wellsite footprint of total singing locations detected at each site were then determined.

\section{Statistical analysis}

A beta regression was used to determine how the total proportion of Ovenbird singing locations on the wellsite in relation to the adjacent forest changed in response to the total number of hypothesized individuals at the site (included as a continuous variable), and canopy cover on the wellsite ( $\mathrm{R}$ package betareg; Cribari-Neto and Zeileis 2010). The pseudo $\mathrm{r}^{2}$ was calculated to assess fit of the model. A significance level of $\alpha=0.05$ was used.

\section{RESULTS}

After removing vocalizations outside the $100 \mathrm{~m}$ buffer around the wellsite, we localized 3206 Ovenbird vocalizations across the 20 wellsites. After summarizing these locations into averaged singing locations, a total of 920 singing locations remained. A total of 38 hypothesized individuals were identified at the 20 sites based on countersinging events. At each site, there were between 0 and 169 instances where more than one hypothesized individual was detected per site based on our countersinging rules. The average number of hypothesized individuals at each wellsite was 1.86 \pm 0.20 . According to the beta regression, Ovenbirds would place a greater proportion of singing locations within the wellsite footprint with increasing canopy cover (Fig. 2, Table 1, pseudo $r^{2}$ $=0.65$ ). However, as the number of hypothesized individuals at each site increased, Ovenbirds placed a lower proportion of singing events within the wellsite footprint (Table 1).

Fig. 2. Plot of the predicted proportion of total Ovenbird (Seiurus aurocapilla) singing events on the wellsite as a function of canopy cover on the wellsite, with the number of conspecifics held constant at two individuals.

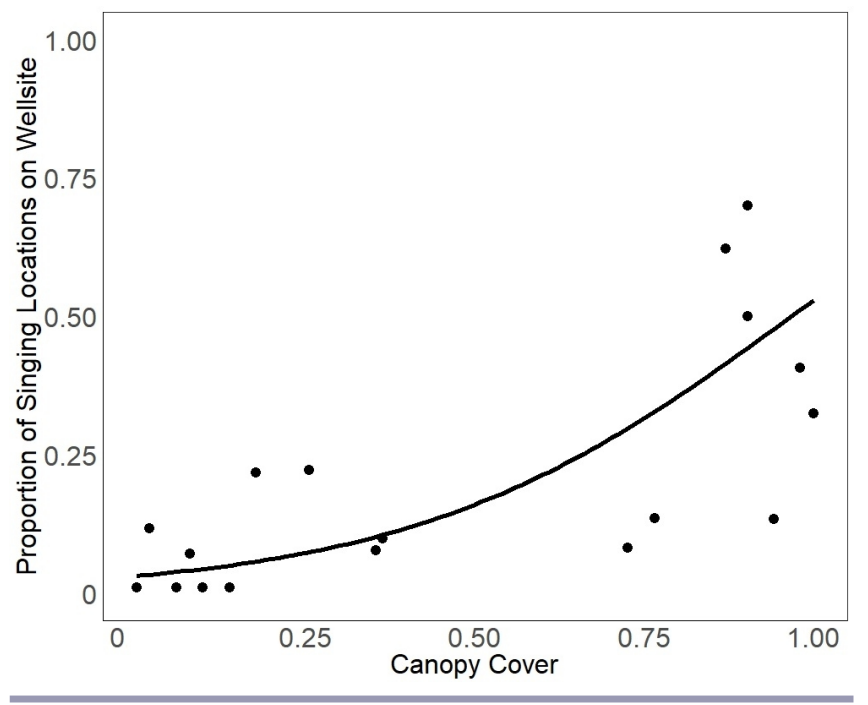


Table 1. Results from beta regression analysis, where response variable is the proportion of total Ovenbird (Seiurus aurocapilla) singing locations on the wellsite.

\begin{tabular}{lcccc}
\hline \hline & Estimate & SE & $\mathrm{z}$ & $\mathrm{p}$ \\
\hline Intercept & -2.24 & 0.40 & -5.53 & $<0.001$ \\
Canopy Cover & 3.55 & 0.52 & 6.86 & $<0.001$ \\
Number of Individuals & -0.60 & 0.19 & -3.80 & 0.002 \\
Phi & 12.5 & 4.14 & 3.02 & 0.003 \\
\hline
\end{tabular}

\section{DISCUSSION}

Previous studies have highlighted the difficulty of detecting the subtle effects of vegetation recovery on songbird behavior and abundance around energy sector disturbances in the boreal forest (Bayne et al. 2016). Conventional point counts are too imprecise, while considerable effort is required to implement spot mapping or territory mapping. Acoustic localization allowed us to determine how Ovenbird behavior changed in response to vegetation recovery, as well as measure local Ovenbird abundance on or near reclaimed wellsites. Increasing canopy cover on wellsites resulted in greater use by Ovenbirds, presumably because of a reduction in perceived predation risk and/or increased leaf litter, which is the main foraging medium for Ovenbirds (Lankau et al. 2013). We hypothesized that presence of conspecifics would result in reduced use of wellsites because these features may act as territory boundaries, which was supported. Our results support the idea Ovenbirds tolerate energy sector disturbances once they are partially regenerated, and will utilize early successional habitats as part of their territories (Haché et al. 2013, Lankau et al. 2013). Although multiple Ovenbirds were observed singing from wellsites, we could not delineate the full territory boundaries of each Ovenbird, and assume our measurements equate to a small proportion of each individual territory.

Relatively few species have been tracked using acoustic localization in terrestrial environments, despite potential for this technology to assist monitoring of various species (Kirschel et al. 2011, Spillmann et al. 2015). Variation in vegetation cover may have influenced the accuracy of localization across wellsites (Mennill et al. 2006, Mennill et al. 2012). Error in localization was moderate in this study, and an attempt was made to account for this by averaging singing locations (Kirschel et al. 2011, Mennill et al. 2012, Wilson et al. 2014). Ovenbirds were an excellent species to study using acoustic localization. They were relatively abundant at study sites, and produced sufficient numbers of vocalizations to allow them to be tracked over the time and area sampled. There were many songs however that could not be localized because of acoustic masking by other vocalizing species. The feasibility of this method is dependent on the number of songs available for localization, which will vary based on species and total number of individuals present (ArayaSalas et al. 2017, Hedley et al. 2017).

Our approach to estimate countersinging events was simplistic, and should be suitable for species that do not display a large degree of individual variation in song. This approach could be used to create approximate territories, and attribute vocalizations to individual birds. Similar approaches have been used to assign vocalizations to individuals and estimate their territories, which requires confirmation that vocalizations have been attributed to the correct individual following classification of songs based on acoustic characteristics (Kirschel et al. 2011, Petrusková et al. 2015). However, one concern is that we created estimates of movement rates and intersong interval from a similar, but independent study system. In addition, our approach was conservative, and may have failed to identify countersinging events that are closer or farther apart in space and time than our guidelines. In instances with very high local abundance of Ovenbirds, our time interval may be too short for all individuals to sing, given that Ovenbirds follow leader/follower dynamics in their singing pattern (Popp 1989).

We did not intend to directly equate our approach to conventional methods like spot mapping because multiple revisits on different days would have to be sampled to collect enough singing locations to construct more representative Ovenbird territories. Standard spot mapping recommends visits to 10-20 hectare grids on up to 10 independent days. To collect data more similar to spot mapping, a larger sampling grid would also be required, as our grid was $10-20 \%$ of the recommended size (Bibby et al. 1992). Because of equipment constraints, it can be infeasible to deploy the ALS at a single location for multiple days during the breeding season. Sampling the same sized area as a 12.25 hectare spot mapping grid would require 64 microphones based on $50 \mathrm{~m}$ spacing, which we believe to be the upper limit that microphones could be spaced given the methods we used (Bayne et al. 2005b). This may become more feasible based on developments of sensor networks that are more affordable, and use of methodologies that can allow increased spacing of microphones (Taylor et al. 2016). However, an additional consideration is that this form of data collection would primarily provide singing locations of males, and additional information standard to spot mapping such as female observations, and breeding behavior will be missed. Therefore, acoustic localization will have to be supplemented with a human observer to collect equivalent data as spot mapping. Further work is also needed to assess differences in processing time from conventional spot-mapping data to localization data, and if bias on bird behavior differs between the two methods.

Increasing canopy cover resulted in increased use of reclaimed wellsites by Ovenbirds, but presence of conspecifics appeared to negatively influence this relationship. Because current reclamation criteria in Alberta do not currently account for songbirds, and further work is required to determine how changes in reclamation practices will impact songbird communities in the future. Future work could use localization to understand the local scale impacts of other types of energy disturbances such as seismic lines and pipelines. Localization is becoming increasingly accessible with the advent of sensor networks that will create more cost-effective arrays, and machine learning algorithms that could allow individuals to be distinguished based on their vocalizations (Kirschel et al. 2009, Taylor et al. 2016). Pairing localization data with high resolution photogrammetry or LiDAR data could provide fundamental insights into fine scale habitat use by songbirds (van Rensen et al. 2015, Cruzan et al. 2016). These data could also be approached using spatially explicit capturerecapture models, or acoustic spatially explicit capture-recapture models to determine density of individuals (Dawson and Efford 
2009, Campbell and Francis 2012, Stevenson et al. 2015). acoustic localization can be used to provide precise spatial locations of different birds concurrently. Technological advances in this method could provide an alternative to conventional methods like territory or spot mapping in the future, when used in combination with other types of data collection (Taylor et al. 2016).

Responses to this article can be read online at:

http://www.ace-eco.org/issues/responses.php/1248

\section{Acknowledgments:}

This research was supported by a Natural Sciences and Engineering Research Council of Canada Collaborative Research and Development Grant (CRDPJ 469943-14) in conjunction with Alberta-Pacific Forest Industries, Cenovus Energy, and ConocoPhillips Canada. Additional funding was provided by the Natural Sciences and Engineering Research Council of Canada (NSERC) CREATE and CRD programs, the Joint Oil Sands Monitoring (JOSM), the Alberta Upstream Petroleum Research Fund (AUPRF), the Canadian Oil Sands Innovation Alliance (COSIA), Environment and Climate Change Canada's Habitat Stewardship Program (HSP), and the University of Alberta Northern Research Awards (UANRA). SW was supported by the Land Reclamation International Graduate School (LRIGS). Special thanks to Cassidy Bodnar, Caroline Walter, Melissa Kucey, and Jocelyn Gregoire for assistance with field data collection. Finally, we thank Hedwig Lankau for providing territory mapping data to inform Ovenbird movement rates.

\section{LITERATURE CITED}

Abacus Datagraphics Limited. 2015. AbaData. Abacus Datagraphics Limited, Red Deer, Alberta, Canada. [online] URL: http://abadata.ca/

Araya-Salas, M., K. Wojczulanis-Jakubas, E. M. Phillips, D. J. Mennill, and T. F. Wright. 2017. To overlap or not to overlap: context-dependent coordinated singing in lekking Long-billed Hermits. Animal Behaviour 124:57-64. http://dx.doi.org/10.1016/ j.anbehav.2016.12.003

Audacity Team. 2017. Audacity: free audio editor and recorder version 2.1.3. [online] URL: http://www.audacityteam.org/ download

Bayne, E. M., S. Boutin, B. Tracz, and K. Charest. $2005 b$. Functional and numerical responses of Ovenbirds (Seiurus aurocapilla) to changing seismic exploration practices in Alberta's boreal forest. Écoscience 12:216-222. http://dx.doi.org/10.2980/ i1 195-6860-12-2-216.1

Bayne, E. M., L. Leston, C. L. Mahon, P. Sólymos, C. Machtans, H. Lankau, J. R. Ball, S. L. van Wilgenburg, S. G. Cumming, T. Fontaine, F. K. A. Schmiegelow, and S. J. Song. 2016. Boreal bird abundance estimates within different energy sector disturbances vary with point count radius. Condor 118:376-390. http://dx.doi. org/10.1650/CONDOR-15-126.1

Bayne, E. M., S. L. van Wilgenburg, S. Boutin, and K. A. Hobson. 2005a. Modeling and field-testing of Ovenbird (Seiurus aurocapillus) responses to boreal forest dissection by energy sector development at multiple spatial scales. Landscape Ecology 20:203-216. http://dx.doi.org/10.1007/s10980-004-2265-9

Bibby, C. J., N. D. Burgess, and D. A. Hill. 1992. Bird census techniques. Academic, London, England.

Blumstein, D.T., D. J. Mennill, P. Clemins, L. Girod, K. Yao, G. Patricelli, J. L. Deppe, A. H. Krakauer, C. Clark, K. A. Cortopassi, S. F. Hanser, B. McCowan, A. M. Ali, and A. N. G. Kirschel. 2011. Acoustic monitoring in terrestrial environments using microphone arrays: applications, technological considerations and prospectus. Journal of Applied Ecology 48:758-767. http://dx. doi.org/10.1111/j.1365-2664.2011.01993.X

Bott, R., G. Chandler, and P. Mckenzie-Brown. 2016. Footprints: the evolution of land conservation and reclamation in Alberta. Kingsley, Calgary, Alberta, Canada.

Campbell, M., and C. M. Francis. 2012. Using microphone arrays to examine effects of observers on birds during point count surveys. Journal of Field Ornithology 83:391-402. http://dx.doi. org/10.1111/j.1557-9263.2012.00389.x

Cortopassi, K. A. 2006. CSE location measurement: a source location tool using correlation sum estimation written for the XBAT analysis platform in MATLAB. Cornell Lab of Ornithology, Ithaca, New York, USA.

Cribari-Neto, F., and A. Zeileis. 2010. Beta regression in R. Journal of Statistical Software 34:1-24. http://dx.doi. org/10.18637/jss.v034.i02

Cruzan, M. B., B. G. Winstein, M. R. Grasty, B. F. Kohrn, E. C. Hendrickson, T. M. Arredondo, and P. G. Thompson. 2016. Small unmanned aerial vehicles (micro-UAVs, drones) in plant ecology. Applications in Plant Sciences 4:1600041. http://dx.doi. org/10.3732/apps.1600041

Darras, K., P. Putz, Fahrurrozi, K. Rembold, and T. Tscharntke. 2016. Measuring sound detection spaces for acoustic animal sampling and monitoring. Biological Conservation 201:29-37. http://dx.doi.org/10.1016/j.biocon.2016.06.021

Dawson, D. K., and M. G. Efford. 2009. Bird population density estimated from acoustic signals. Journal of Applied Ecology 46:1201-1209. http://dx.doi.org/10.1111/j.1365-2664.2009.01731. $\mathrm{x}$

Downing, D. J., and W. W. Pettapiece. 2006. Natural regions and subregions of Alberta. Publication Number T/852. Government of Alberta, Edmonton, Alberta, Canada.

Ehnes, M., and J. R. Foote. 2015. Comparison of autonomous and manual recording methods for discrimination of individually distinctive Ovenbird songs. Bioacoustics 24:111-121. http://dx. doi.org/10.1080/09524622.2014.994228

Environment and Climate Change Canada. 2017. Historical climate data. Environment and Climate Change Canada, Gatineau, Québec, Canada. [online] URL: http://climate.weather. gc.ca

Figueroa, H., and M. Robbins. 2007. XBAT (version 5). Cornell Lab of Ornithology, Ithaca, New York, USA.

Fitzsimmons, L. P., J. R. Foote, L. M. Ratcliffe, and D. J. Mennill. 2008. Eavesdropping and communication networks revealed 
through playback and an acoustic location system. Behavioural Ecology 19:824-829. http://dx.doi.org/10.1093/beheco/arn036

Floyd, D. A., and J. E. Anderson. 1987. A comparison of three methods for estimating plant cover. Journal of Ecology 75:221-228. http://dx.doi.org/10.2307/2260547

Haché, S., M.-A. Villard, and E. M. Bayne. 2013. Experimental evidence for an ideal free distribution in a breeding population of a territorial songbird. Ecology 94:861-869. http://dx.doi. org/10.1890/12-1025.1

Hayes, S. A., D. K. Mellinger, D. A. Croll, D. P. Costa, and J. F. Borsani. 2000. An inexpensive passive acoustic system for recording and localizing wild animal sounds. Journal of the Acoustical Society of America 107:3552-3555. http://dx.doi. org/10.1121/1.429424

Heap, S., P. Byrne, and D. Stuart-Fox. 2012. The adoption of landmarks for territorial boundaries. Animal Behaviour 83:871-878. http://dx.doi.org/10.1016/j.anbehav.2012.01.016

Hedley, R. W., Y. Huang, and K. Yao. 2017. Direction-of-arrival estimation of animal vocalizations for monitoring animal behavior and improving estimates of abundance. Avian Conservation and Ecology 12(1):6. http://dx.doi.org/10.5751/ ACE-00963-120106

Jones, D. L., and R. Ratnam. 2009. Blind location and separation of callers in a natural chorus using a microphone array. Journal of the Acoustical Society of America 126:895-910. http://dx.doi. org/10.1121/1.3158924

Kirschel, A. N. G., M. L. Cody, Z. T. Harlow, V. J. Promponas, E. E. Vallejo, and C. E. Taylor. 2011. Territorial dynamics of Mexican Ant-thrushes Formicarius moniliger revealed by individual recognition of their songs. Ibis 153:255-268. http://dx. doi.org/10.1111/j.1474-919X.2011.01102.x

Kirschel, A. N. G., D. A. Earl, Y. Yao, I. A. Escobar, E. Vilches, E. E. Vallejo, and C. E. Taylor. 2009. Using songs to identify individual Mexican Antthrush Formicarius moniliger: comparison of four classification methods. Bioacoustics 19:1-20. http://dx.doi. org/10.1080/09524622.2009.9753612

Lankau, H. E., E. M. Bayne, and C. S. Machtans. 2013. Ovenbird (Seiurus aurocapilla) territory placement near seismic lines is influenced by forest regeneration and conspecific density. Avian Conservation and Ecology 8(1):5. http://dx.doi.org/10.5751/ ACE-00596-080105

Machtans, C. S. 2006. Songbird response to seismic lines in the western boreal forest: a manipulative experiment. Canadian Journal of Zoology 84:1421-1430. http://dx.doi.org/10.1139/ z06-134

Mahon, C. L., G. Holloway, P. Sólymos, S. G. Cumming, E. M. Bayne, F. K. A. Schmiegelow, and S. J. Song. 2016. Community structure and niche characteristics of upland and lowland western boreal birds at multiple spatial scales. Forest Ecology and Management 361:99-116. http://dx.doi.org/10.1016/j.foreco.2015.11.007

Mathworks Inc. 2014. MATLAB and statistics toolbox release. Mathworks Inc., Natick, Massachusetts, USA. [online] URL: https://www.mathworks.com/products/matlab.html
McGregor, P. K., T. Dabelsteen, C. W. Clark, J. L. Bower, and J. Holland. 1997. Accuracy of a passive acoustic location system: empirical studies in terrestrial habitats. Ethology Ecology \& Evolution 9:269-286. http://dx.doi.org/10.1080/08927014.1997.9522887

Mennill, D. J. 2011. Individual distinctiveness in avian vocalizations and the spatial monitoring of behaviour. Ibis 153:235-238. http://dx.doi.org/10.1111/j.1474-919X.2011.01119. $\mathrm{x}$

Mennill, D. J., M. Battison, D. R. Wilson, J. R. Foote, and S. M. Doucet. 2012. Field test of an affordable, portable, wireless microphone array for the spatial monitoring of animal ecology and behaviour. Methods in Ecology and Evolution 3:704-712. http://dx.doi.org/10.1111/j.2041-210X.2012.00209.x

Mennill, D. J., J. M. Burt, K. M. Fristrup, and S. L. Vehrencamp. 2006. Accuracy of an acoustic location system for monitoring the position of duetting songbirds in tropical forest. Journal of the Acoustical Society of America 119:2832-2839. http://dx.doi. org/10.1121/1.2184988

Petrusková, T., I. Pišvejcová, A. Kinštová, T. Brinke, and A. Petrusek. 2016. Repertoire-based individual acoustic monitoring of a migratory passerine bird with complex song as an efficient tool for tracking territorial dynamics and annual return rates. Methods in Ecology and Evolution 7:274-284. http://dx.doi. org/10.1111/2041-210X.12496

Popp, J. W. 1989. Temporal aspects of singing interactions among territorial Ovenbirds (Seiurus aurocapillus). Ethology 82:127-133. http://dx.doi.org/10.1111/j.1439-0310.1989.tb00493.x

Powter, C., N. Chymko, G. Dinwoodie, D. Howat, A. Janz, R. Puhlmann, T. Richens, D. Watson, H. Sinton, K. Ball, A. Etmanski, B. Patterson, L. Brocke, and R. Dyer. 2012. Regulatory history of Alberta's industrial land conservation and reclamation program. Canadian Journal of Soil Science 92:39-51. http://dx. doi.org/10.4141/cjss2010-033

Quantum GIS Development Team. 2016. Quantum GIS geographic information system. [online] URL: http://www.qgis. org/en/site

R Core Team. 2017. R: A language and environment for statistical computing. R Foundation for Statistical Computing, Vienna, Austria. [online] URL: http://www.R-project.org/

Shonfield, J., and E. M. Bayne. 2017. Autonomous recording units in avian ecological research: current use and future applications. Avian Conservation and Ecology 12(1):14. http://dx.doi. org/10.5751/ACE-00974-120114

Sólymos, P., S. M. Matsuoka, D. Stralberg, N. K. S. Barker, and E. M. Bayne. 2018. Phylogeny and species traits predict bird detectability. Ecography. http://dx.doi.org/10.1111/ecog.03415

Spillmann, B., M. A. van Noordwijk, E. P. Willems, T. M. Setia, U. Wipfli, and C. P. van Schaik. 2015. Validation of an acoustic location system to monitor Bornean orangutan (Pongo pygmaeus wurmbii) long calls. American Journal of Primatology 77:767-776. http://dx.doi.org/10.1002/ajp.22398

Stepanian, P. M., K. G. Horton, D. C. Hille, C. E. Wainwright, P. B. Chilson, and J. F. Kelly. 2016. Extending bioacoustic monitoring of birds aloft through flight call localization with a 
three-dimensional microphone array. Ecology and Evolution 6:7039-7046. http://dx.doi.org/10.1002/ece3.2447

Stevenson, B. C., D. L. Borchers, R. Altwegg, R. J. Swift, D. M. Gillespie, and G. J. Measey. 2015. A general framework for animal density estimation from acoustic detections across a fixed microphone array. Methods in Ecology and Evolution 6:38-48. http://dx.doi.org/10.1111/2041-210X.12291

Taylor, C. E., Y. Huang, and K. Yao. 2016. Distributed sensor swarms for monitoring bird behavior: an integrated system using wildlife acoustics recorders. Artificial Life Robotics 21:268-273. http://dx.doi.org/10.1007/s10015-016-0295-4

van Rensen, C. K., S. E. Nielsen, B. White, B. Vinge, and V. J. Lieffers. 2015. Natural regeneration of forest vegetation on legacy seismic lines in boreal habitats in Alberta's oil sands region. Biological Conservation 184:127-135. http://dx.doi.org/10.1016/j. biocon.2015.01.020

van Wilgenburg, S. L., K. A. Hobson, E. M. Bayne, and N. Koper. 2013. Estimated avian nest loss associated with oil and gas exploration and extraction in the Western Canadian Sedimentary Basin. Avian Conservation and Ecology 8(2):9. http://dx.doi. org/10.5751/ACE-00585-080209

Wilson, D. R., M. Battiston, J. Brzustowski, and D. J. Mennill. 2014. Sound finder: a new software approach for localizing animals recorded with a microphone array. Bioacoustics 23:99-112. http://dx.doi.org/10.1080/09524622.2013.827588

Yip, D. A., L. Leston, E. M. Bayne, P. Sólymos, and A. Grover. 2017. Experimentally derived detection distances from audio recordings and human observers enable integrated analysis of point count data. Avian Conservation and Ecology 12(1):11. http:// dx.doi.org/10.5751/ACE-00997-120111 